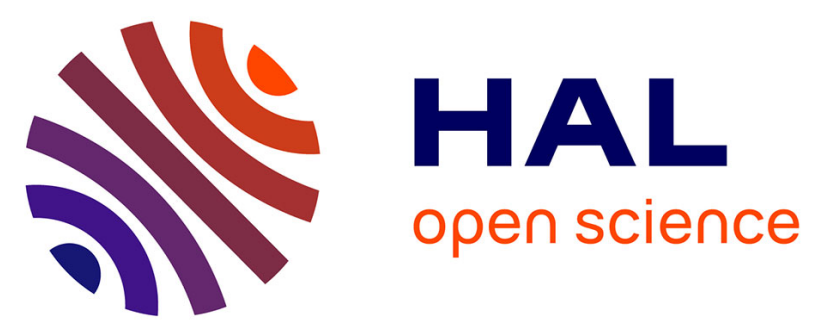

\title{
Decimetric-scale two-dimensional distribution of soil phosphorus after 20 years of tillage management and maintenance phosphorus fertilization
}

\author{
A. N. Cambouris, A. J. Messiga, N. Ziadi, I. Perron, Christian Morel
}

\section{To cite this version:}

A. N. Cambouris, A. J. Messiga, N. Ziadi, I. Perron, Christian Morel. Decimetric-scale twodimensional distribution of soil phosphorus after 20 years of tillage management and maintenance phosphorus fertilization. Soil Science Society of America Journal, 2017, 81 (6), pp.1606-1614. 10.2136/sssaj2017.03.0101 . hal-02620079

\section{HAL Id: hal-02620079 \\ https://hal.inrae.fr/hal-02620079}

Submitted on 25 May 2020

HAL is a multi-disciplinary open access archive for the deposit and dissemination of scientific research documents, whether they are published or not. The documents may come from teaching and research institutions in France or abroad, or from public or private research centers.
L'archive ouverte pluridisciplinaire HAL, est destinée au dépôt et à la diffusion de documents scientifiques de niveau recherche, publiés ou non, émanant des établissements d'enseignement et de recherche français ou étrangers, des laboratoires publics ou privés.

\section{(ㅇ)(1) $\$$}

Distributed under a Creative Commons Attribution - NonCommercial - NoDerivatives $\mid 4.0$ 


\section{Decimetric-Scale Two-Dimensional Distribution of Soil Phosphorus after 20 Years of Tillage Management and Maintenance Phosphorus Fertilization}

\author{
A. N. Cambouris* \\ Quebec Research and \\ Development Centre \\ 2560 Hochelaga Blvd. \\ Quebec, QC \\ Canada G1V 2J3
}

\author{
A. J. Messiga \\ Agassiz Research and \\ Development Centre \\ P.O. Box 1000 \\ 6947 Hwy. 7 \\ Agassiz, BC \\ Canada V0M 1A0
}

\author{
N. Ziadi \\ I. Perron \\ Quebec Research and \\ Development Centre \\ 2560 Hochelaga Blvd. \\ Quebec, QC \\ Canada G1V 2J3
}

C. Morel

INRA, UMR 1391 ISPA INRA

Bordeaux Sciences Agro

F-33140 Villenave

d'Ornon

France

\section{Core Ideas}

- 2-D distribution of Mehlich-3 P across seeding row had no spatial pattern in no-till and moldboard plow.

- Horizontal distribution of Mehlich-3 P was less sensitive to extrinsic factors.

- Soil-surface $\mathbf{P}$ accumulation in no-till is due in part to $P$ recycled by corn and soybean.

- Surface $\mathbf{P}$ accumulation in no-till is also due to the replenishment of solution $\mathbf{P}$ by residual $\mathbf{P}$.
Improving soil test $\mathbf{P}$ assessment at plot scale is essential for productivity in conservation agriculture systems. We characterized the distribution of Mehlich-3 $\mathbf{P}\left(\mathbf{P}_{\mathrm{M} 3}\right)$ concentrations at the decimetric scale with depth on either side of the sowing row in no-till (NT) and moldboard plow (MP) plots fertilized with $35 \mathrm{~kg} \mathrm{P} \mathrm{ha}^{-1}$ every $2-\mathrm{yr}$ in a corn-soybean rotation (20-yr). A total of 996 soil samples $(83$ samples $\times 2$ depths $[0-5$ and $5-20 \mathrm{~cm}] \times 6$ plots [3 blocks each MP and NT]) were collected at corn harvest in 2012. The average $P_{M 3}$ concentrations in the 0 - to $5-\mathrm{cm}$ layer were 35.7 and $63.4 \mathrm{mg} \mathrm{kg}^{-1}$ in MP and NT, respectively. The $P_{M 3}$ concentration in the 5- to $20-\mathrm{cm}$ depth was similar between MP and NT and averaged $32.0 \mathrm{mg} \mathrm{kg}^{-1}$. The horizontal distribution of $\mathbf{P}_{\mathrm{M} 3}$ concentrations in these plots was less sensitive to extrinsic factors including tillage, $P$ fertilization and soil depth. High coefficients of variation were associated with $\mathrm{P}_{\mathrm{M} 3}$ data in both MP (77 and 63\% at $0-5$ and 5-20 cm, respectively) and NT plots (46 and 66\% at $0-5$ and $5-20 \mathrm{~cm}$, respectively). It is possible that this strong overall variability overshadowed any $\mathbf{P}_{\mathrm{M} 3}$ pattern that could have been introduced by NT management. Geostatistical semivariance analysis indicated a predominance of random spatial dependence in most plots, except two plots (one MP and one NT) with moderate spatial structures. The 2-D geospatial model related to tillage was not detected by the sampling grid used at this experimental site. Therefore, a similar sampling strategy would be appropriate and could be recommended for these two tillage systems in this long-term corn-soybean rotation.

Abbreviations: $\mathrm{Al}_{\mathrm{M} 3}$, Mehlich-3 aluminum; $\mathrm{CV}$, coefficient of variation; $\mathrm{MP}$, moldboard plow; NT, no-till; $\mathrm{P}_{\mathrm{M} 3}$, Mehlich-3 phosphorus; 2-D, two-dimensional.

S OWING CROPS without tillage of soil (the no-till [NT] method) is now an established practice worldwide to mitigate soil erosion and runoff (Friedrich et al., 2012). The implementation of NT management in the current agricultural context has been made possible by the use of herbicides and improved technologies (Pittelkow et al., 2015). It is estimated that approximately 9\% (125 Mha) of global arable land is under NT management (Friedrich et al., 2012). In eastern Canada during the 2011 cropping season, the NT acreage was approximately $25 \%$, in comparison with $18.5 \%$ in 2001, and further increases are projected by 2020 (Statistics Canada, 2016). A blend of NT management with well-planned crop rotation and residue retention can improve and sustain the productivity of cropland and contribute to overall food security (Pittelkow et al., 2015).

Surveys conducted in various parts of the world have shown that NT practices have raised relevant general concerns about environmental issues surrounding soil and landscape protection and climate change (Dodd and Sharpley, 2016). The major environmental issue to date is the risk of increased leaching of dissolved reactive phosphorus (P) (Simard et al., 2000; Djodjic et al., 2004). To some extent, and de-

Soil Sci. Soc. Am. J. 81:1606-1614

doi:10.2136/sssaj2017.03.0101

Received 28 Mar. 2017.

Accepted 24 July 2017.

*Corresponding author: (athyna.cambouris@agr.gc.ca).

(C) Soil Science Society of America. This is an open access article distributed under the CC BY-NC-ND

license (http://creativecommons.org/licenses/by-nc-nd/4.0/) 
spite a reduction in erosion and sediment loss with NT, P enrichment of the particles transported due to legacy $\mathrm{P}$ can also result in increased particulate P loss (Rodrigues et al., 2016). Puustinen et al. (2005) found that the transport of dissolved reactive $P$ on clayey sloped fields in a boreal climate increased by $348 \%$ under NT management in comparison with plowed soils.

A literature review on $\mathrm{P}$ distribution in the soil profile of fertilized NT cropland shows greater soil test $P$ concentrations in the top 5-cm layer and, to some extent, down to the 10-cm depth, as well as a marked depletion of $\mathrm{P}$ in subsequent sublayers (Abdi et al., 2014; Cade-Menun et al., 2010). Messiga et al. (2012) observed low soil test $\mathrm{P}$ concentration in the 10 - to 20 -cm layer of fertilized NT plots in comparison with MP plots, indicating that under NT, $\mathrm{P}$ was depleted in this layer. This gradient of $\mathrm{P}$ concentration is due in part to year-to-year broadcast or band application of $\mathrm{P}$ fertilizer at or near the same sowing row, to the absence of mixing of $P$ fertilizers with soil and crop residues left on the soil surface after harvest, and to the subsequent leaching of $P$ from crop residues (Duiker and Beegle, 2006). Phosphorus stratification has implications for crop nutrition, since P depletion in the rooting zone, where $\mathrm{P}$ is needed by plant roots, may reduce crop yield (Lupwayi et al., 2006). Several strategies have been suggested to address this issue, including strategic tillage (Dang et al., 2015) and the collection of separate soil samples from different layers to capture the vertical variability found in the rooting zone and thus ensure better fertilizer $P$ recommendations and placement methods (Cade-Menun et al., 2010).

Given that $\mathrm{P}$ fertilizers are applied at a shallow depth (about 4 to $5 \mathrm{~cm}$ below the soil surface), and that sowing row positions do not change over time, NT management can also result in a lateral distribution of $\mathrm{P}$. This is often overlooked compared to the common evaluation of $\mathrm{P}$ concentration gradients with depth. Evidence of such two-dimensional (2-D) spatial variability, both vertical and horizontal, in NT was highlighted in a 2-yr study under a corn (Zea mays L.) and soybean [Glycine max (L.) Merr.] rotation with crops planted at $76-\mathrm{cm}$ row spacing (Fernández and Schaefer, 2012). Those authors observed no change in soil test $\mathrm{P}$ concentrations under NT for broadcast application across all sampling positions with respect to the crop row for the top 30 $\mathrm{cm}$ of the soil. In contrast, increases in soil P levels were observed at the crop row relative to interrow positions at maintenance or recommended fertilizer $P$ rates for subsurface-band fertilization (at $15 \mathrm{~cm}$ below the soil) (Farmaha et al., 2012; Fernández and Schaefer, 2012) or injection (at $10 \mathrm{~cm}$ below the soil) (Duiker and Beegle, 2006). Continuous band applications of $P$ in the same soil volume result in a substantial localized increase in soil $P$ test levels and depletion in the rest of the rooting zone.

The long-term NT site (from 1992 onward) at the L'Acadie Experimental Farm of Agriculture and Agri-Food Canada’s SaintJean-sur-Richelieu Research and Development Centre (SaintJean-sur-Richelieu RDC), in the province of Quebec, Canada, has been the object of extensive research over the past decade. At this site, granular P fertilizers are surface-band-applied as triple superphosphate $(5 \mathrm{~cm}$ from the seeding row) year to year at or near the same sowing row using a disk opener (3-4 cm deep) according to local recommendations (CRAAQ, 2010). Water, Mehlich-3 P ( $\left.\mathrm{P}_{\mathrm{M} 3}\right)$, and other soil P fraction accumulations were observed in the surface soil layer under NT in comparison with moldboard plow (MP) (Messiga et al., 2012; Shi et al., 2013). In addition, Messiga et al. (2012) found that $P$ stratification down the soil profile in NT was influenced by P rates. However, it is not clear if continuous surface-band application of $P$ at maintenance $P$ rates in the same location results in significant horizontal variability between the sowing row and the interrow space and whether this distribution would influence soil $\mathrm{P}$ assessment and thus soil sampling procedures and subsequent fertilizer P recommendations. We hypothesized that the year-to-year surface-band application of fertilizer at maintenance $P$ rates at or near the same sowing row and the absence of mixing of $P$ fertilizers can induce a spatial structure for soil P in NT-managed soils that can be detected on either side of the sowing row. The objective of this study was to characterize the decimetric spatial variability of soil $\mathrm{P}$ on either side of the sowing row in both NT and MP plots using classical and 2-D geostatistical analyses (semivariograms).

\section{MATERIALS AND METHODS}

\section{Site Description and Experimental Design}

The study was conducted at an existing long-term experimental site established in 1992 at the L'Acadie $\left(45^{\circ} 18^{\prime} \mathrm{N}\right.$, $73^{\circ} 21^{\prime}$ W) Experimental Farm of Agriculture and Agri-Food Canada's Saint-Jean-sur-Richelieu RDC, in the province of Quebec, Canada (Ziadi et al., 2014). Briefly, the soil is a poorly drained deep clay loam classified as Humic Orthic Gleysol (Typic Haplaquept under the US Soil Taxonomy [Soil Survey Staff, 2010]). It originated from a fluvial deposit and evolved from a fine-textured greyish-to-brown parent material. The topography is flat with slope less than $1 \%$ and tile drainage was installed. The field was cropped to alfalfa (Medicago sativa $\mathrm{L}$.) before its conversion to a corn-soybean rotation in 1992. The topsoil $(0-15 \mathrm{~cm})$ initially had organic matter of $38 \mathrm{~g} \mathrm{~kg}^{-1}, \mathrm{P}_{\mathrm{M} 3}$ of $135 \mathrm{~kg} \mathrm{P} \mathrm{ha}^{-1}$, a phosphorus saturation index $(\mathrm{P} / \mathrm{Al})_{\mathrm{M} 3}$ of $4.3 \%$, and $\mathrm{pH}$ water of 6.3 (Ziadi et al., 2014). The mean annual temperature at the study site is $6.3^{\circ} \mathrm{C}$ with $1100 \mathrm{~mm}$ of total annual precipitation. The experimental design was a split plot with tillage practices (MP and NT) assigned to main plots and a factorial of three nitrogen $(\mathrm{N})$ rates $\left(0,80\right.$, and $\left.160 \mathrm{~kg} \mathrm{ha}^{-1}\right)$ and three $\mathrm{P}$ rates $(0$, 17.5 , and $35 \mathrm{~kg} \mathrm{ha}^{-1}$ ) assigned to subplots with four replicates. The experimental plots were $25 \mathrm{~m}$ long by $4.5 \mathrm{~m}$ wide (six rows of corn). The MP treatment consisted of one MP operation (20 $\mathrm{cm}$ deep) in fall after harvest, followed by disking and harrowing (10 cm deep) each spring before seeding. For the NT treatment, the plots were ridge-tilled from 1992 to 1997 and flat-directseeded from 1998 onward, with crop residues left on the ground after harvest. Granular triple superphosphate was band-applied ( $5 \mathrm{~cm}$ from the seeding row) to only the corn phase of the rotation using a disk opener (3-4 cm deep) according to local recommendations. The P treatments were band-applied in a single application at planting as commercial triple superphosphate $(0-$ 
46-0). Nitrogen treatments consisted of two split band-applications, first at seeding with additions of 0,48 , and $48 \mathrm{~kg} \mathrm{~N} \mathrm{ha}^{-1}$ as urea, and second at approximately the eight-leaf stage with additions of 0,32 , and $112 \mathrm{~kg} \mathrm{~N}^{-1}$ side-dressed as ammonium nitrate. All plots received potassium at $41.5 \mathrm{~kg} \mathrm{ha}^{-1}(0-0-60)$ band-applied at planting in 1992 and 2007; this application was based on soil analysis and local recommendations (CRAAQ, 2010). There were six rows in each subplot, with corn sown at $74 \times 10^{3}$ plants ha $^{-1}$ and soybean sown at $45 \times 10^{4}$ plants ha $^{-1}$.

\section{Soil Sampling}

Six experimental plots receiving $35 \mathrm{~kg} \mathrm{P} \mathrm{ha}^{-1}$ and $160 \mathrm{~kg} \mathrm{~N} \mathrm{ha}^{-1}$, the local recommended rates, before corn seeding were selected within the experimental set-up for this study (MP and NT tillage practices replicated in three blocks). Each plot was treated as an individual field for the spatial variability study: $\mathrm{MP}_{1}(\mathrm{MP}$ from the first block), $\mathrm{MP}_{2}$ (MP from the second block), $\mathrm{MP}_{3}$ (MP from the third block), $\mathrm{NT}_{1}$ (NT from the first block), $\mathrm{NT}_{2}$ (NT from the second block), and $\mathrm{NT}_{3}$ (NT from the third block). A nested grid sampling scheme was implemented on the two middle rows of each of the six units to limit border effects (Nyiraneza et al., 2011). The principal grid $(2.5-\mathrm{m}$ $\times 0.38-\mathrm{m}$ distance between each of the 35 sampling points) consisted of seven transects (perpendicular to row direction) and five transects (located in three interrows and two corn rows, i.e., third and fourth rows in the plot) (Fig. 1). Three of the seven transects had more intensive interrow sampling points $(0.076-\mathrm{m}$ distance between the sampling points perpendicular to the row; 16 additional sampling points per transect). Each sampling point was sampled at the 0 - to 5 - and the 5- to $20-\mathrm{cm}$ soil depths after corn harvest in October 2012. A total of 996 soil samples (83 samples per depth and experimental plot $\times 2$ depths $\times 6$ experimental units) were collected for the spatial variability study (Fig. 1). The soils were air-dried, sieved through a 2-mm sieve as suggested for soil $\mathrm{P}$ testing methods, and analyzed.

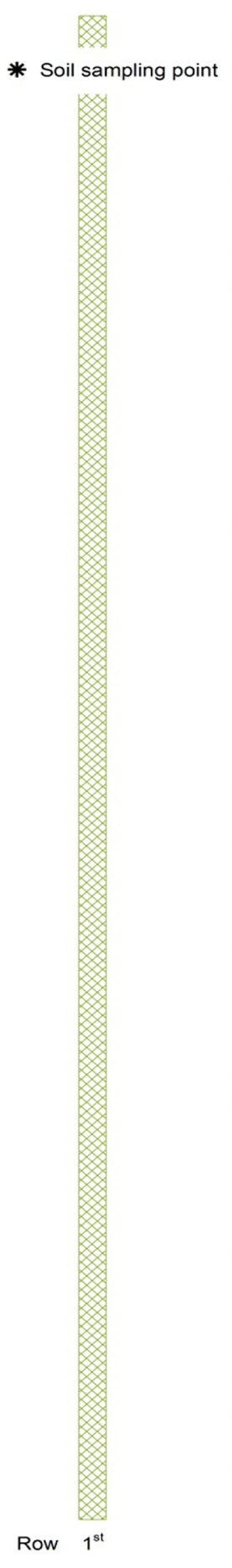

\section{Soil Analysis}

The soils were extracted with a Mehlich-3 solution according to Ziadi and Tran (2007). The $\mathrm{P}_{\mathrm{M} 3}$ and Mehlich-3 aluminum (Al) $\left(\mathrm{Al}_{\mathrm{M} 3}\right)$ concentrations $\left(\mathrm{mg} \mathrm{kg}^{-1}\right)$ were determined by inductively coupled plasma optical emission spectroscopy (ICP-OES) (Optima 4300 DV spectrometer; PerkinElmer, Shelton, CT).

\section{Statistical and Geostatistical Analysis}

Data were analyzed in the classical way using descriptive statistics in SAS v.9.3 (SAS Institute, 2010) to investigate $\mathrm{P}_{\mathrm{M} 3}$, $\mathrm{Al}_{\mathrm{M} 3}$ and $(\mathrm{P} / \mathrm{Al})_{\mathrm{M} 3}$ and their spatial variability. The minimum,

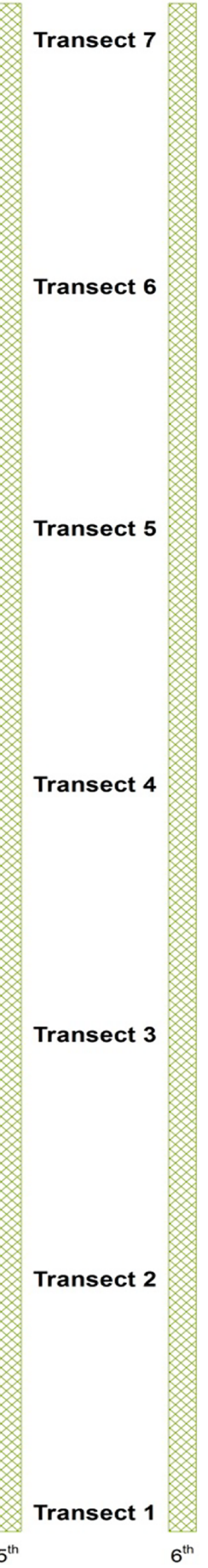

Fig. 1. Distribution of sampling points in the experimental plot. 
maximum, mean, median, coefficient of variation $(\mathrm{CV})$, and standard error of the mean (SEM) were determined for each location and depth. The CV and SEM were calculated using Eq. [1] and [2], respectively:

$$
\begin{gathered}
\mathrm{CV}=\frac{\sqrt{\frac{\sum(X-\bar{X})}{n}}}{\bar{X}} \times 100 \\
\mathrm{SEM}=\frac{\sqrt{\frac{\sum(X-\bar{X})}{n}}}{\sqrt{n}}
\end{gathered}
$$

where $X$ is the measured parameter, $\bar{X}$ is the mean value of the sample population, and $n$ is the size of the sample population.

The mixed procedure of SAS v.9.3 (SAS Institute, 2010) was used to assess the effects of tillage, depth, and sampling location. Block was used as random effect, and tillage, depth, sampling location, and the two- and three-way interactions involving the three factors were used as fixed effects.

The 2-D geostatistical analyses (semivariance and block kriging) were performed on $\mathrm{P}_{\mathrm{M} 3}\left(\mathrm{mg} \mathrm{kg}^{-1}\right)$ data for each of the six experimental units and depths $\left(\mathrm{MP}_{1}\right.$ at $0-5 \mathrm{~cm}, \mathrm{MP}_{1}$ at $5-20$ $\mathrm{cm}, \mathrm{MP}_{2}$ at $0-5 \mathrm{~cm}, \mathrm{MP}_{2}$ at $5-20 \mathrm{~cm}, \mathrm{MP}_{3}$ at $0-5 \mathrm{~cm}, \mathrm{MP}_{3}$ at $5-20 \mathrm{~cm}, \mathrm{NT}_{1}$ at $0-5 \mathrm{~cm}, \mathrm{NT}_{1}$ at $5-20 \mathrm{~cm}, \mathrm{NT}_{2}$ at $0-5 \mathrm{~cm}$, $\mathrm{NT}_{2}$ at $5-20 \mathrm{~cm}, \mathrm{NT}_{3}$ at $0-5 \mathrm{~cm}$, and $\mathrm{NT}_{3}$ at $5-20 \mathrm{~cm}$ ) with $\mathrm{GS}^{+}$v.9 software (Robertson, 2008; Webster and Oliver, 2007). The prediction of spatial dependence or continuity of $\mathrm{P}_{\mathrm{M} 3}$ at non-sampling points required a theoretical semivariogram that was constructed on the basis of experimental semivariograms. Experimental semivariograms, the main component of kriging, were calculated with Eq. [3]:

$$
\gamma(b)=\frac{1}{2 n} \sum_{i=1}^{n}\left\{Z\left(x_{i}\right)-Z\left(x_{i}+b\right)\right\}^{2}
$$

where $\gamma(b)$ is the semivariogram for the lag distance $h ; n$ is the number of sample pairs separated by the lag distance $h ; Z\left(x_{i}\right)$ is the measured $\mathrm{P}_{\mathrm{M} 3}$ at the $i$ th location; $Z\left(x_{i}+h\right)$ is the measured $\mathrm{P}_{\mathrm{M} 3}$ at the $(i+\mathrm{h})$ th location; and $i$ is the index to design location.

Various models were fitted to the semivariogram to estimate simulated $\mathrm{P}_{\mathrm{M} 3}$ for non-sampling points. Model selections for semivariograms were performed on the basis of a goodnessof-model-fit criterion. The corresponding nugget $\left(\mathrm{C}_{0}\right)$, partial sill $(C)$, sill $\left(\mathrm{C}_{0}+\mathrm{C}\right)$, and range values of the best-fitting theo-

Table 1. Results of the analysis of variance of Mehlich-3 $\mathbf{P}\left(\mathbf{P}_{\mathrm{M3}}\right)$ and $\mathrm{Al}\left(\mathrm{Al}_{\mathrm{M3}}\right)$ concentrations and $\mathrm{P}$ saturation ratio $(\mathrm{P} / \mathrm{Al})_{\mathrm{M} 3}$ in a corn-soybean rotation under moldboard plow and no-till soils.

$P$ values

\begin{tabular}{lrrrr} 
& $\mathbf{d f}$ & $\mathbf{P}_{\mathbf{M} 3}$ & $\mathbf{A l}_{\mathbf{M} 3}$ & $(\mathbf{P} / \mathbf{A l})_{\mathbf{M} 3}$ \\
\hline Tillage & 1 & $<0.001$ & 0.003 & $<0.001$ \\
Depth & 1 & $<0.001$ & 0.028 & $<0.001$ \\
Tillage $\times$ Depth & 1 & 0.007 & 0.002 & $<0.001$ \\
Absolute position & 10 & 0.721 & 0.859 & 0.232 \\
Absolute position $\times$ Tillage & 10 & 0.648 & 0.788 & 0.706 \\
Absolute position $\times$ Depth & 10 & 0.749 & 0.999 & 0.600 \\
Absolute position $\times$ Tillage $\times$ Depth & 10 & 0.980 & 0.999 & 0.892 \\
\hline
\end{tabular}

retical model were calculated. The values of the nugget/sill ratios $\left[\mathrm{C}_{0} /\left(\mathrm{C}_{0}+\mathrm{C}\right)\right]$ were used to evaluate the spatial dependence or structure of the $\mathrm{P}_{\mathrm{M} 3}$ data (Oliver and Webster, 2014), where $\mathrm{C}_{0}$ / $\left(\mathrm{C}_{0}+\mathrm{C}\right)$ less than $25 \%$ suggests that the variable has a strong spatial dependence, $\mathrm{C}_{0} /\left(\mathrm{C}_{0}+\mathrm{C}\right)$ between 25 and $75 \%$ suggests that the variable has a moderate spatial dependence, and $\mathrm{C}_{0} /\left(\mathrm{C}_{0}+\mathrm{C}\right)$ above $75 \%$ suggests that the variable has a low spatial dependence. Block kriging interpolation technique was used to produce the spatial distribution maps of $\mathrm{P}_{\mathrm{M} 3}$ for the studied plots.

\section{RESULTS \\ Mehlich-3 Phosphorus and Aluminum and Phosphorus Saturation Ratio}

The $\mathrm{P}_{\mathrm{M} 3}$ and $\mathrm{Al}_{\mathrm{M} 3}$ concentrations and the $(\mathrm{P} / \mathrm{Al})_{\mathrm{M} 3}$ were affected only by tillage, and the extent varied with sampling depth (Table 1). Mehlich-3 P concentrations across the three MP plots ranged from 10.6 to $285.0 \mathrm{mg} \mathrm{kg}^{-1}$ in the 0 -to 5 -cm layer and from 9.1 to $185.7 \mathrm{mg} \mathrm{kg}^{-1}$ in the 5 - to $20-\mathrm{cm}$ layer (Fig. 2a). In the three NT plots, $\mathrm{P}_{\mathrm{M} 3}$ concentrations ranged from 14.0 to $209.6 \mathrm{mg} \mathrm{kg}^{-1}$ in the 0 to 5 -cm layer and from 5.8 to $184.8 \mathrm{mg} \mathrm{kg}^{-1}$ in the 5 - to 20 -cm layer (Fig. 2a). Average $\mathrm{P}_{\mathrm{M} 3}$ concentrations in the 0 - to 5 -cm layer were 35.7
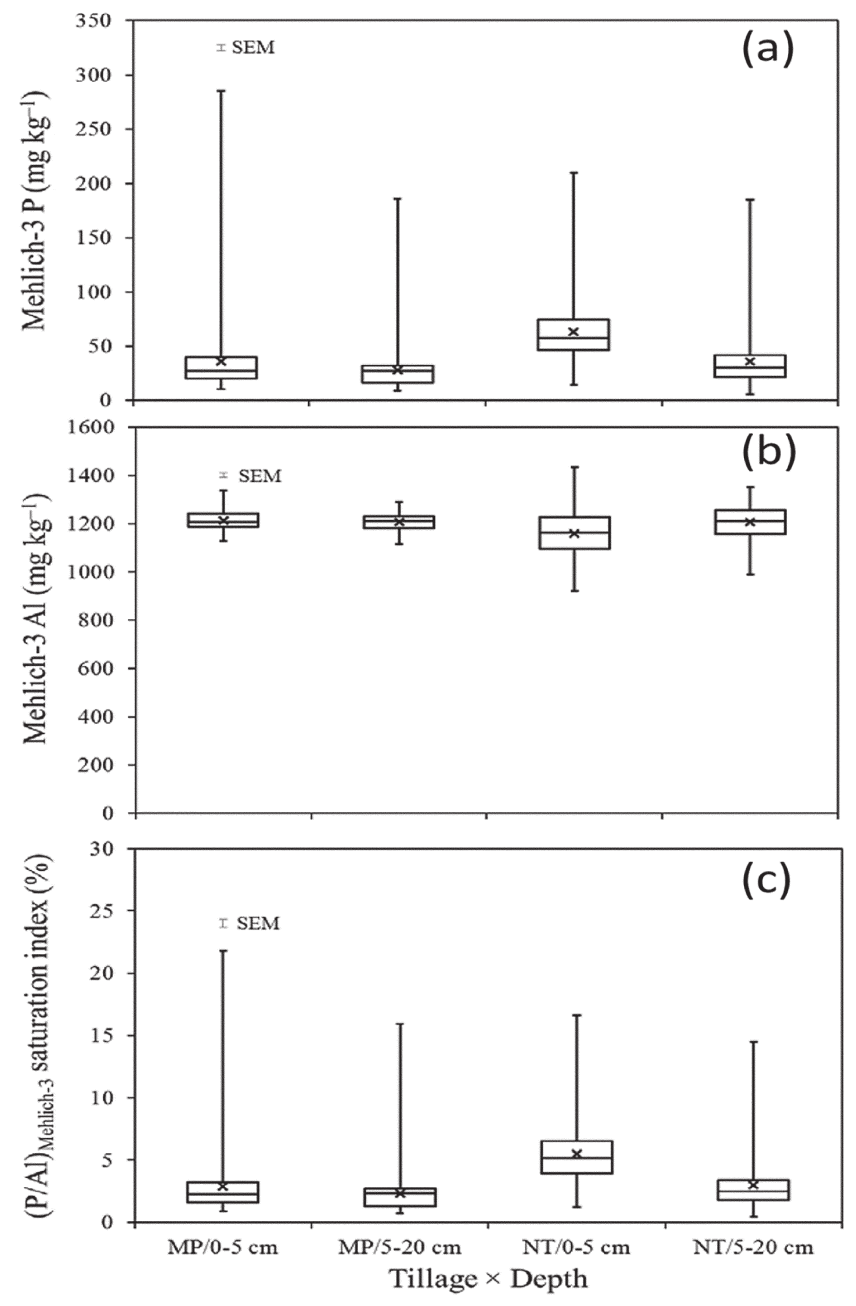

Fig. 2. (a) Mehlich-3 $P$, (b) Mehlich-3 $\mathrm{Al}$ and (c) $\mathrm{P}$ saturation index $(\mathrm{P} / \mathrm{Al})_{\mathrm{M} 3}$ in moldboard plow (MP) and no-till (NT) systems in relation to soil depth $(0-5$ and 5-20 cm). SEM represents standard error of the mean. 
and $63.4 \mathrm{mg} \mathrm{kg}^{-1}$ in $\mathrm{MP}$ and $\mathrm{NT}$, respectively. In contrast, $\mathrm{P}_{\mathrm{M} 3}$ concentration in the 5 - to 20 -cm layer was similar between MP and NT and averaged $32.0 \mathrm{mg} \mathrm{kg}^{-1}$. Under MP, the CVs of $\mathrm{P}_{\mathrm{M} 3}$ concentration were 77 and $63 \%$ in the 0 - to 5- and 5- to 20 -cm layers, respectively. Under NT, the CVs of $\mathrm{P}_{\mathrm{M} 3}$ concentration were 46 and $66 \%$ in the 0 - to 5 - and 5-to 20 -cm layers, respectively. Mehlich-3 $\mathrm{Al}$ concentrations across the three MP plots ranged from 1127 to $1338 \mathrm{mg} \mathrm{kg}^{-1}$ in the 0 - to 5 -cm layer and from 1116 to $1290 \mathrm{mg} \mathrm{kg}^{-1}$ in the 5- to 20-cm layer (Fig. $2 \mathrm{~b})$. In the three $\mathrm{NT}$ plots, $\mathrm{Al}_{\mathrm{M} 3}$ concentrations ranged from 922 to $1433 \mathrm{mg} \mathrm{kg}^{-1}$ in the 0 - to 5 -cm layer and from 990 to $1351 \mathrm{mg} \mathrm{kg}^{-1}$ in the 5 - to 20 -cm layer. Average $\mathrm{Al}_{\mathrm{M} 3}$ concentrations in the 0 - to 5 -cm layer were 1214 and $1160 \mathrm{mg} \mathrm{kg}^{-1}$ in MP and NT, respectively. In contrast, $\mathrm{Al}_{\mathrm{M} 3}$ concentration in the 5- to 20-cm layer was similar between MP and NT and averaged $1206 \mathrm{mg} \mathrm{kg}^{-1}$. Under $\mathrm{MP}$, the $\mathrm{CVs}$ of $\mathrm{Al}_{\mathrm{M} 3}$ concentration were 3.2 and $2.9 \%$ in the 0 - to 5 - and 5-to 20-cm layers, respectively. Under $\mathrm{NT}$, the $\mathrm{CVs}$ of $\mathrm{Al}_{\mathrm{M} 3}$ concentration were 8.2 and $5.5 \%$ in the 0 - to 5- and 5- to 20-cm layers, respectively. The $(\mathrm{P} / \mathrm{Al})_{\mathrm{M} 3}$ ratios across the three $\mathrm{MP}$ plots ranged from 0.90 to $21.80 \%$ in the 0 - to 5 -cm layer and from 0.74 to $2.72 \%$ in the 5- to 20-cm layer (Fig. 2c). In the three NT plots, the $(\mathrm{P} / \mathrm{Al})_{\mathrm{M} 3}$ ratios ranged from 1.25 to $16.62 \%$ in the 0 - to $5-\mathrm{cm}$ layer and from 0.45 to $14.51 \%$ in the 5 - to $20-\mathrm{cm}$ layer. The average $(\mathrm{P} / \mathrm{Al})_{\mathrm{M} 3}$ ratios in the 0 - to 5 -cm layer were 2.91 and $5.50 \%$ in $\mathrm{MP}$ and $\mathrm{NT}$, respectively. In contrast, the $(\mathrm{P} / \mathrm{Al})_{\mathrm{M} 3}$ ratios in the 5- to $20-\mathrm{cm}$ depth were similar between $\mathrm{MP}$ and NT and averaged 2.66\%. Under MP, the CVs of the $(\mathrm{P} / \mathrm{Al})_{\mathrm{M} 3}$ ratio were 80 and $64 \%$ in the 0 - to 5 - and 5-to 20 -cm layers, respectively. Under $\mathrm{NT}$, the $\mathrm{CVs}$ of the $(\mathrm{P} / \mathrm{Al})_{\mathrm{M} 3}$ ratio were 43 and $67 \%$ in the 0 - to 5- and 5- to 20-cm layers, respectively.

\section{Spatial Prediction of Mehlich-3 Phosphorus}

Anisotropy was not evident in the directional semivariograms of $\mathrm{P}_{\mathrm{M} 3}$ for any of the six studied experimental units and two depths. Therefore, isotropic models were fitted to the experimental semivariograms of $\mathrm{P}_{\mathrm{M} 3}$ concentrations across the six studied experimental plots and two depths. In the MP and NT plots, the pure nugget model was obtained as the dominant best fit for all except the 5- to 20-cm depth of the $\mathrm{MP}_{3}$ plot and the 0 - to $5-\mathrm{cm}$ of the $\mathrm{NT}_{1}$ plot, where exponential models best described the experimental semivariogram (Table 2). The semivariogram models displayed positive nugget effects, which may be a result of sampling errors, random inherent variability, or short-range variability. The degree of spatial dependence in the six studied plots and two depths was evaluated by the nugget/sill ratio. The nugget/sill ratio was $50 \%$ for the 5 - to 20 -cm depth in the $\mathrm{MP}_{3}$ plot and $100 \%$ for the rest of the MP plots and depths. Similarly, the nugget/sill ratio was $41 \%$ for the 0 - to 5 -cm depth in the $\mathrm{NT}_{1}$ plot and was $100 \%$ for the rest of the NT plots and depths. On average, spatial dependence was low in most plots except for $\mathrm{MP}_{3}$ at 5 to $20 \mathrm{~cm}$ (Fig. 3) and $\mathrm{NT}_{1}$ at 0 to $5 \mathrm{~cm}$ (Fig. 4), where moderate spatial dependence was obtained. The range, a measure of the spatial continuity between two sampling points, was determined only for the spherical model and equalled 125 $\mathrm{cm}$ for $\mathrm{MP}_{3}$ at 5 to $20 \mathrm{~cm}$ and $127 \mathrm{~cm}$ for $\mathrm{NT}_{1}$ at 0 to $5 \mathrm{~cm}$ (Table 2). All models were evaluated using cross-validation analysis (Table 2). The cross-validation coefficients of determination $\left(R^{2}\right)$ were 0.30 for $\mathrm{MP}_{3}$ at 5 to $20 \mathrm{~cm}$ and 0.82 for $\mathrm{NT}_{1}$ at 0 to 5 $\mathrm{cm}$ but were 0.0 for the other experimental units and depths. In addition, the root mean square error values were large and varied between 8.90 and 40.56 in the MP plots and between 18.56 and 29.32 in the NT plots, indicating poor model prediction.

Table 2. Semivariogram and kriging parameters describing the spatial variability of Mehlich-3 $\mathbf{P}$ concentrations at 0 to 5 and 5 to $20 \mathrm{~cm}$ layers of a corn-soybean rotation under moldboard plow (MP) and no-till (NT) soils.

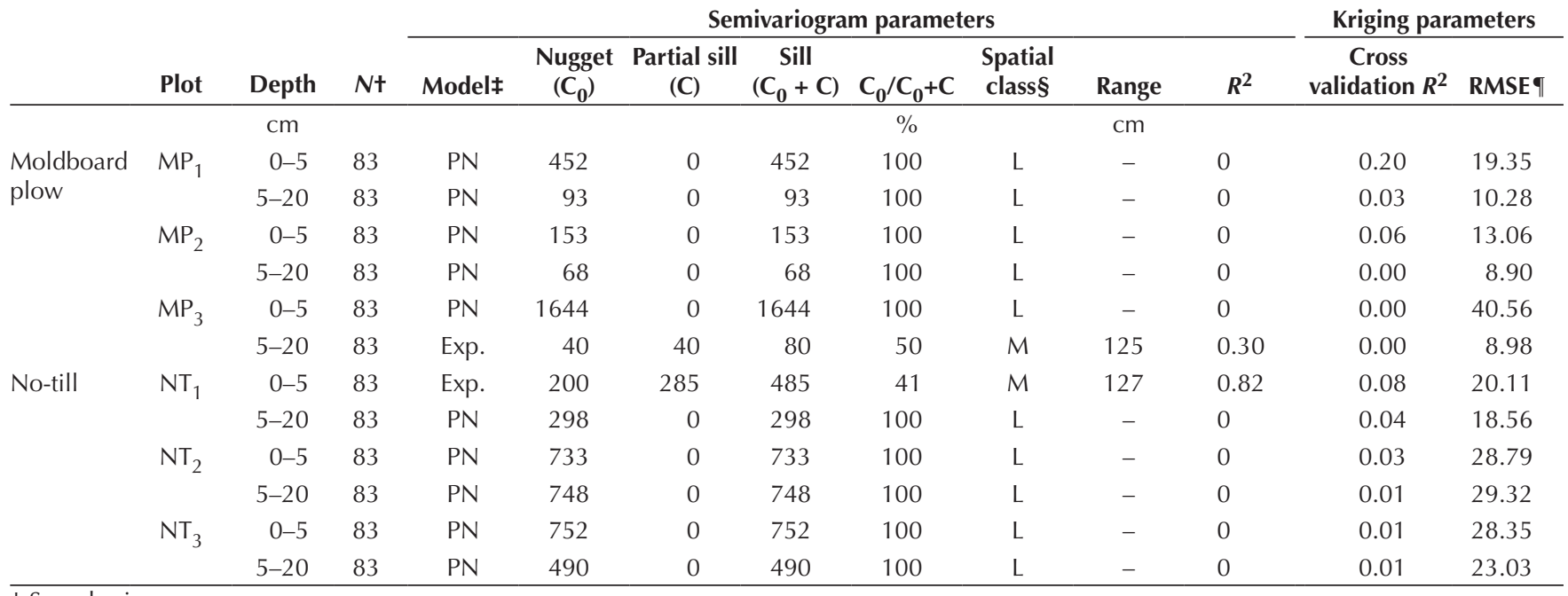

† Sample size.

₹ Exp., exponential; PN, pure nugget.

$\S \mathrm{L}$, random spatial dependence (>75\%); M, moderate (25-75\%); S, strong (<25\%) (Oliver and Webster, 2014).

I RMSE, root mean squared error. 


\section{DISCUSSION}

\section{Mehlich-3 Phosphorus and Aluminum}

We did not detect any differences in the horizontal distribution of $\mathrm{P}_{\mathrm{M} 3}$ on either side of the sowing rows in the 0 - to 5- and 5- to 20-cm layers in the MP- and NT-managed plots (Fig. 5).
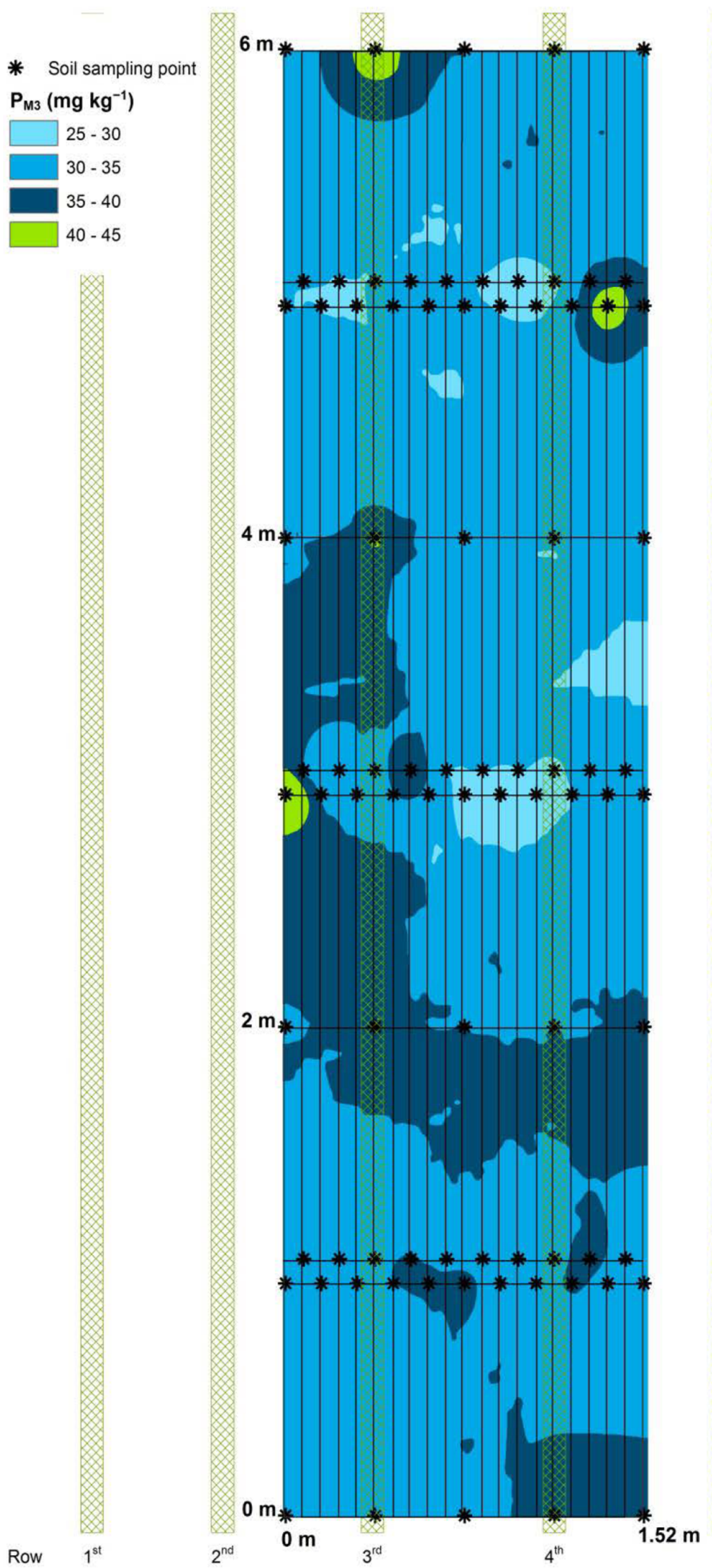
$5^{\text {th }} \quad 6^{\text {th }}$

Fig. 3. Prediction map of the spatial distribution of Mehlich-3 $\mathbf{P}\left(\mathbf{P}_{\mathrm{M3}}\right)$ concentrations $\left(\mathrm{mg} \mathrm{kg}^{-1}\right)$ in the 5- to $20-\mathrm{cm}$ soil depth after $20 \mathrm{yr}$ of moldboard plow management and maintenance phosphorus fertilization. The green bands represent six corn rows. The dark lines perpendicular to the green bands represent seven transects. The dark stars represent 83 sampling points.
Transect 7

Transect 6

Transect 5

Transect 4

Transect 3

Transect 2

Transect 1

Geostatistical semivariance analysis further supported this result, ability, or short-range variability. Pure nugget and exponential models were defined for NT and MP, although the first model was predominant. Pure nugget models indicate that the $\mathrm{P}_{\mathrm{M} 3}$ concentration is not spatially correlated. The 2-D geostatistical semivariance analysis is in line with the general statistical analysis indicating that the horizontal distribution of $\mathrm{P}_{\mathrm{M} 3}$ concentration in these plots was less sensitive to extrinsic factors including tillage, $P$ fertilization and depth. Random spatial dependence indicates a lack of structural variability and a predominance of random factors (Nyiraneza et al., 2011). Previous studies reported moderate spatial dependence for extractable $P$ (Chang et al., 1999; Nyiraneza et al., 2011) using grid dimensions varying from 0.18 to 15 ha. The wide range obtained in $\mathrm{MP}_{3}$ at 5 to $20 \mathrm{~cm}$ (Fig. 3) and $\mathrm{NT}_{1}$ at 0 to $5 \mathrm{~cm}$ (Fig. 4) suggests the presence of some autocorrelation that limited the accuracy of predictions in the two types of tillage management. The occurrence of $\mathrm{P}_{\mathrm{M} 3}$ concentrations above critical agro-environmental levels (CRAAQ, 2010) can be observed in plots $\mathrm{MP}_{3}$ at 5 to $20 \mathrm{~cm}$ (Fig. 3) and $\mathrm{NT}_{1}$ at 0 to $5 \mathrm{~cm}$ (Fig. 4) in this site. However, considering the moderate spatial structure of $\mathrm{P}_{\mathrm{M} 3}$ it is difficult to derive based on our results any distribution pattern that could be generalized to other MP or NT sites. Nyiraneza et al. (2011) also found range values for $P$ extracted with anion exchange membranes varying from 40 to $711 \mathrm{~cm}$. For most model selections, the $R^{2}$ values indicated a poor fit regardless of the type of management. In this study, the cross-validation $R^{2}$ values were very low for MP and NT, regardless of depth. Therefore, the 2-D geospatial model related to fertilization and tillage mode was not detected by the sampling grid. The mismatches detected between the observed and predicted $\mathrm{P}_{\mathrm{M} 3}$ concentrations could be explained by the small sample size used in this study. We used 83 data points to construct the semivariograms, and Webster and Oliver (1992) indicated that semivariograms computed from fewer than 100 pieces of data are unreliable. The number of samples used in this study was limited by the small size of the experimental plots $(25 \mathrm{~m} \times 4.5 \mathrm{~m})$ and the intensive sampling that is performed year to year for other studies (Messiga et al., 2012; Poirier et al., 2009; Shi et al., 2013). 
The results of the conventional statistical analysis as well as the geostatistical analysis indicate that the development of sampling procedures for capturing the variability that occurs under fertilized NT plots needs further study or new tools.

This structured horizontal $\mathrm{P}_{\mathrm{M} 3}$ variability was not observed (Fig. 5). It is possible that the strong overall variability, as evidenced by the high CV values (Nolin et al., 1991), overshadowed any $\mathrm{P}_{\mathrm{M} 3}$ pattern that could have been introduced by NT management practices. Messiga et al. (2012) found high interannual variability associated with $\mathrm{P}_{\mathrm{M} 3}$ concentrations in the studied plots. It is also interesting to note that the studied plots are characterized by a low $\mathrm{P}$ budget ( $\mathrm{P}$ input $-\mathrm{P}$ output), as fertilizers were applied only every 2 yr to the corn phase of the rotation according to local recommendations (CRAAQ, 2010). The low P budget probably played a significant role in the overshadowing of any expected $\mathrm{P}_{\mathrm{M} 3}$ pattern that could have been introduced by NT management practices. The average cumulative $\mathrm{P}$ budget in the studied plots was $65 \mathrm{~kg} \mathrm{P} \mathrm{ha}^{-1}$ during the period of 1992 to 2010, which corresponds to an annual $\mathrm{P}$ budget of $3.6 \mathrm{~kg} \mathrm{Pha}^{-1} \mathrm{yr}^{-1}$ (Messiga et al., 2012). Studies assessing changes in $P_{M 3}$ as influenced by the $\mathrm{P}$ budget showed that for every unit of $\mathrm{P}$ budget, $\mathrm{P}_{\mathrm{M} 3}$ varies between 0.07 and 0.16 unit (Messiga et al., 2012; Zhang et al., 2004). An annual P budget of $3.6 \mathrm{~kg} \mathrm{P} \mathrm{ha}^{-1} \mathrm{yr}^{-1}$ might therefore not be sufficient to result in overall significant changes in $\mathrm{P}_{\mathrm{M} 3}$ across the NT plot and thus on either side of the sowing row. Messiga et al. (2012) also showed that the changes in $\mathrm{P}_{\mathrm{M} 3}$ concentrations in the studied P-fertilized NT plots were affected more by annual soil test $\mathrm{P}$ variability than by the P budget. Our results are in line with those obtained in East Central Illinois by Fernández and Schaefer (2012), who found no change in soil test $\mathrm{P}$ levels for broadcast $\mathrm{P}$ in NT soils across all sampling positions with respect to the crop row for the top $30 \mathrm{~cm}$ of the soil at a balanced P budget. Similarly, Farmaha et al. (2012) showed that for highly positive $P$ budgets, soil test $P$ increased at all sampling positions with respect to the crop row within the 10- to 20-cm depth increment. Duiker and Beegle (2006) also found a peak in $\mathrm{P}_{\mathrm{M} 3}$ concentration at the location of starter fertilizer injection in the 0 - to 5 -cm layer, but no pattern of $\mathrm{P}_{\mathrm{M} 3}$ decrease away from the sowing row was noticeable. In a clayed sloped field in a boreal climate, dissolved reactive $\mathrm{P}$ was found to increase by $348 \%$ under NT in comparison with plowed soils (Puustinen et al., 2005). This suggests that fertilizer $P$ applied to NT soils interacts easily with runoff water, thus facilitating the lateral movement of $\mathrm{P}$. Given the low and limited range of the P budget in our studied NT plots, it is difficult to suggest any change in soil sampling procedures under fertilized NT management. It will be necessary to conduct more studies with a wide
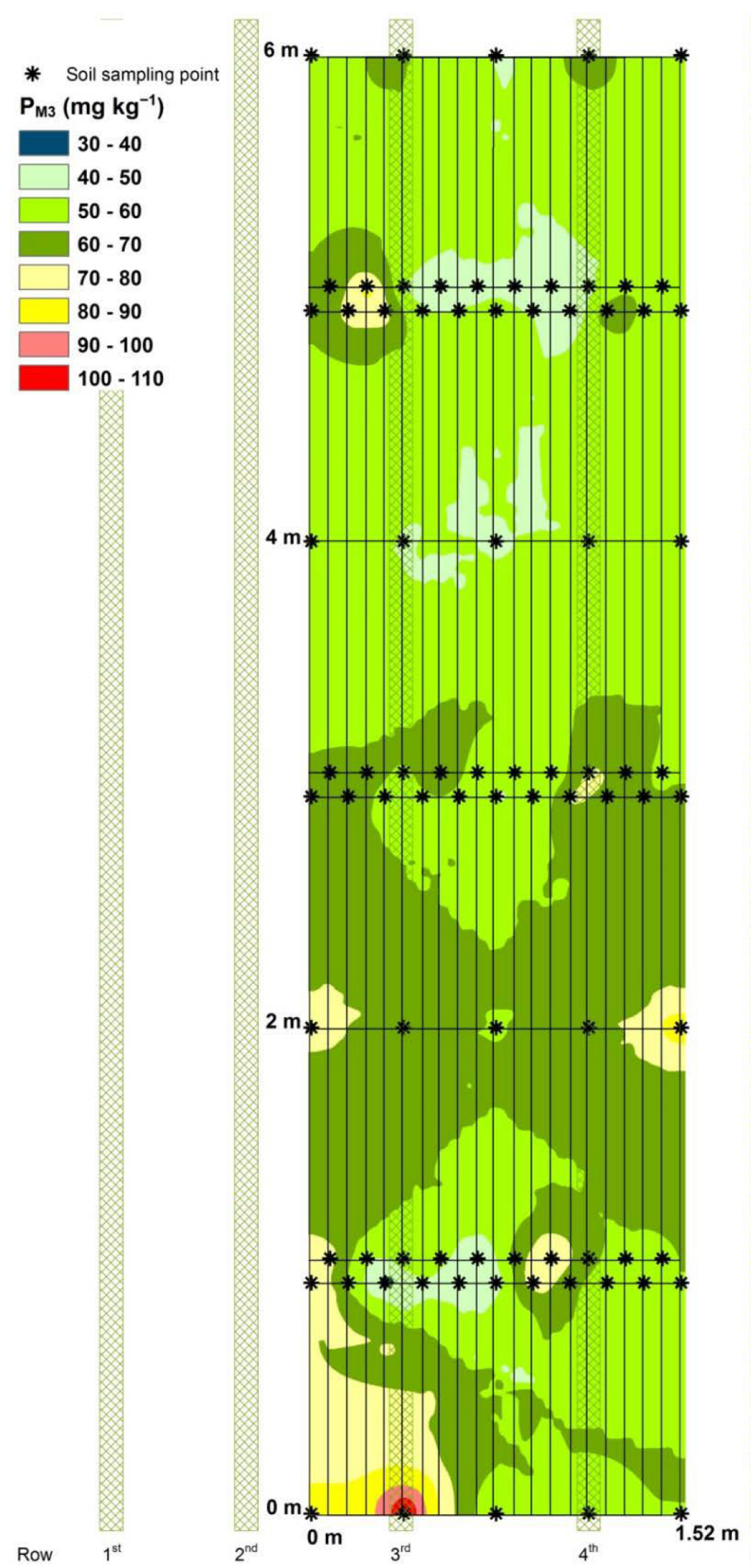

Transect 5

Transect 4

Transect 3

Transect 2

Transect 1 $5^{\text {th }}$ $6^{\text {th }}$

Fig. 4. Prediction map of the spatial distribution of Mehlich-3 $P\left(P_{M 3}\right)$ concentrations $\left(\mathrm{mg} \mathrm{kg}^{-1}\right)$ in the 0 - to $5-\mathrm{cm}$ soil depth after $20 \mathrm{yr}$ of no-till management and maintenance phosphorus fertilization. The green bands represent six corn rows. The dark lines perpendicular to the green bands represent seven transects. The dark stars represent 83 sampling points. 

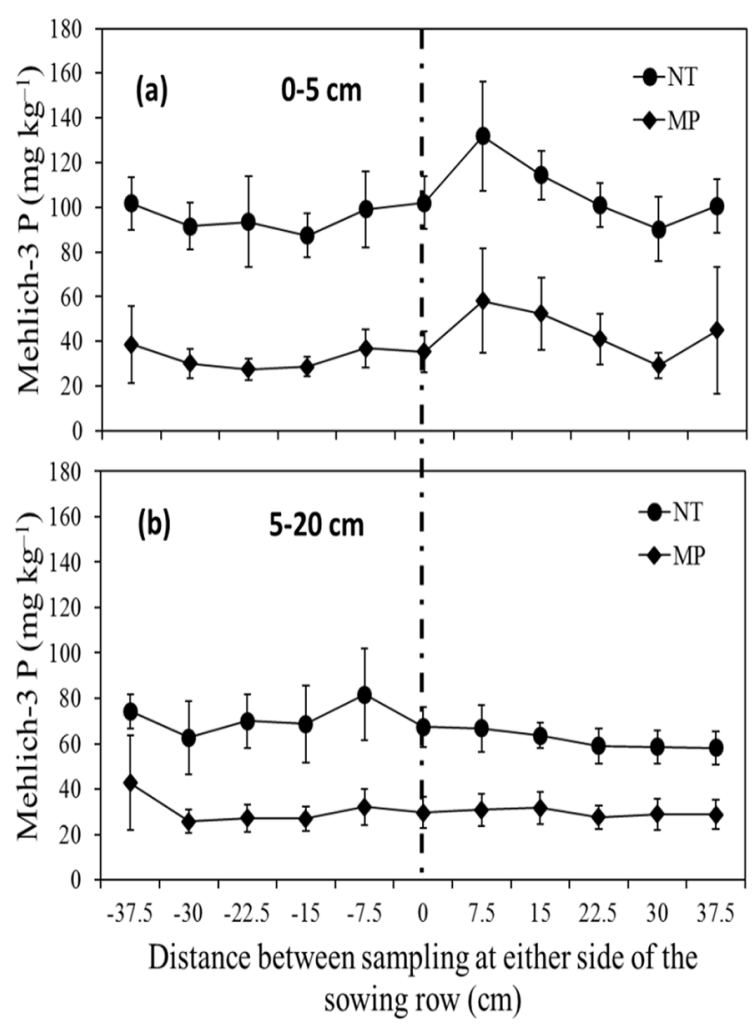

Fig. 5. Horizontal distribution of Mehlich-3 P on either side of the sowing row at 0 to $5 \mathrm{~cm}$ (a) and 5 to $20 \mathrm{~cm}$ (b) in corn-soybean under moldboard plow (MP) and no-till (NT) soils. Soil samples were collected after harvest in fall 2012. Error bars represent standard deviation of the mean.

range of $\mathrm{P}$ budgets to include the variability associated with fertilization practices in cereal-legume rotations in Eastern Canada.

The absence of horizontal $\mathrm{P}_{\mathrm{M} 3}$ variability under NT could further be explained by the dynamics of the residual $\mathrm{P}$ fraction as assessed by P fractionation. Results obtained by Shi et al. (2013) in the same studied plots showed that the residual P fraction under P fertilization was less in the NT plots than in the MP plots after $16 \mathrm{yr}$ of cultivation. Those authors concluded that over the long-term, the residual $\mathrm{P}$ fraction replenishes the solution $\mathrm{P}$ ions and therefore contributes to the greater labile $\mathrm{P}$ levels observed in the P-fertilized NT. A similar process occurs in P-unfertilized plots. Syers et al. (2008) found that even after decades of cropping without $P$ additions, soils were still able to release measurable $\mathrm{P}$ and sustain agricultural production. Long-term studies on various soils showed that crop yield does not decrease over time without $\mathrm{P}$ fertilization, which supports the assumption of a greater presence of $\mathrm{P}$ in the solid phase (Messiga et al., 2012, 2015). The transfer of $P$ ions at the solid-solution interface is controlled by rapid and slow reactions, with equilibration periods lasting up to $5 \mathrm{yr}$ owing to solid-state and pore diffusion (Messiga et al., 2012, 2015). Therefore, as plant roots deplete the $\mathrm{P}$ on either side of the sowing rows not affected by the band-applied fertilizer $P$, the residual $P$ fraction partly contributes to replenishing the labile $\mathrm{P}$ pool. This labile $\mathrm{P}$ pool is made up mainly of resin $\mathrm{P}$ and $\mathrm{NaHCO}_{3}$-inorganic $\mathrm{P}$ fractions, thus overshadowing the $\mathrm{P}_{\mathrm{M} 3}$ variability that could have been introduced by band-applied fertilizer P. Insight obtained from further studies looking at the differential dynamics of residual $\mathrm{P}$ and labile $\mathrm{P}$ in the sowing row and on either side of it would be valuable.

The $\mathrm{P}_{\mathrm{M} 3}$ concentrations and $(\mathrm{P} / \mathrm{Al})_{\mathrm{M} 3}$ ratio values and trends are also in line with previous studies conducted at this site and elsewhere that showed greater accumulations of soil test $\mathrm{P}$ in the topsoil of NT plots in comparison with MP plots, a process that is also described as P stratification. Messiga et al. (2010) used soil cores $(0-5 \mathrm{~cm})$ collected from this site in September 2007 and showed that after one and three freeze-thaw cycles, water-extractable $\mathrm{P}$ and $\mathrm{P}_{\mathrm{M} 3}$ concentrations were greater under $\mathrm{NT}$ than under MP. In another study considering the long-term impact of tillage practices and P fertilization on soil P status, Messiga et al. (2012) used samples collected in 2010 to highlight greater soil test P accumulations in the 0 - to $5-\mathrm{cm}$ depth under NT than under MP. Studies conducted at other sites on P distribution in the soil profile of fertilized NT plots also showed greater soil test P concentrations in the top $5-\mathrm{cm}$ layer and, to some extent, down to $10 \mathrm{~cm}$, as well as a depletion of $\mathrm{P}$ in sublayers where most of the roots develop (Cade-Menun et al., 2010; Lupwayi et al., 2006). In this longterm experiment, $\mathrm{P}$ fertilizers are band-applied in the NT plots, and the $\mathrm{P}$ budgets are close to equilibrium. This suggests that $\mathrm{P}$ accumulation at the soil surface across NT plots is due in part to $\mathrm{P}$ recycled by corn and soybean plants (Eckert and Johnson, 1985). The agronomic implications of $\mathrm{P}$ stratification in the soil profile of NT-managed soils are well documented and include reduced $\mathrm{P}$ uptake and lower crop yield due to the depletion of $\mathrm{P}$ in lower layers where plant roots develop (Lupwayi et al., 2006). Our results also suggest that there may be less need for starter $P$ fertilizer in long-term NT management owing to the high available P levels in the 0 - to $5-\mathrm{cm}$ depth where the seeds are placed. The environmental implications of $\mathrm{P}$ stratification include enhanced $\mathrm{P}$ losses in runoff due to $P$ concentrations in the topsoil that are above critical environmental risk values (Duiker and Beegle, 2006).

\section{CONCLUSIONS}

The 2-D distribution of $\mathrm{P}_{\mathrm{M} 3}$ concentrations with soil depth and perpendicularly to the seeding row did not show a spatial pattern in the NT and MP plots. Therefore, the 2-D geospatial model related to tillage mode was not detected by the sampling grid used in this experiment. The horizontal distribution of $\mathrm{P}_{\mathrm{M} 3}$ concentration in these plots was less sensitive to extrinsic factors including tillage, $\mathrm{P}$ fertilization and depth. It is possible that the mismatches between the observed and predicted $\mathrm{P}_{\mathrm{M} 3}$ concentrations could be explained by the small sample size used in this study. Interestingly, the $\mathrm{P}_{\mathrm{M} 3}$ concentrations were greater in the 0to 5 -cm layer than in the 5- to 20-cm layer in the NT plots. Given that $\mathrm{P}$ fertilizers are band-applied in the NT plots and that the $\mathrm{P}$ budgets are close to equilibrium in this long-term experiment, $\mathrm{P}$ accumulation at the soil surface across the NT plots is due in part to $\mathrm{P}$ recycled by corn and soybean plants and to the replenishment of the solution P ions by the residual P fraction. According to the sampling design used in this experiment, we conclude that NT and MP soil management requires the same sampling strategy for establishing $\mathrm{P}$ fertilization recommendations. 


\section{ACKNOWLEDGMENTS}

This study was supported by CENTRE SÈVE and the Sustainable Agriculture Environmental Systems (SAGES) program of Agriculture and Agri-Food Canada. We thank Mario Deschênes, Claude Lévesque, André Martin, and Sylvie Michaud for their technical assistance.

\section{REFERENCES}

Abdi, D., B.J. Cade-Menun, N. Ziadi, and L.-E. Parent. 2014. Long-term impact of tillage practices and phosphorus fertilization on soil phosphorus forms as determined by ${ }^{31} \mathrm{P}$ nuclear magnetic resonance spectroscopy. J. Environ. Qual. 43:1431-1441. doi:10.2134/jeq2013.10.0424

Cade-Menun, B.J., M.R. Carter, D.C. James, and C.W. Liu. 2010. Phosphorus forms and chemistry in the soil profile under long-term conservation tillage: A phosphorus-31 nuclear magnetic resonance study. J. Environ. Qual. 39:1647-1656. doi:10.2134/jeq2009.0491

Chang, J., D.E. Clay, C.G. Carlson, D. Malo, S.A. Clay, J. Lee, and M. Ellsbury. 1999. Precision farming protocol: Part I. Grid distance and soil nutrient impact on the reproducibility of spatial variability measurements. Precis. Agric. 1:277-289. doi:10.1023/A:1009921024451

CRAAQ. 2010. Reference guide for crop fertilization [in French]. 2nd ed. Centre de référence en agriculture et agroalimentaire du Québec, Quebec City, QC, Canada.

Dang, Y.P., P.W. Moody, M.J. Bell, N.P. Seymour, R.C. Dalal, D.M. Freebairn, and S.R. Walker. 2015. Strategic tillage in no-till farming systems in Australia's northern grains-growing regions: II. Implications for agronomy, soil and environment. Soil Tillage Res. 152:115-123. doi:10.1016/j. still.2014.12.013

Djodjic, F., K. Börling, and L. Bergström. 2004. Phosphorus leaching in relation to soil type and soil phosphorus content. J Environ. Qual. 33:678-684. doi: 10.2134/jeq2004.0678

Dodd, R.J., and A.N. Sharpley. 2016. Conservation practice effectiveness and adoption: Unintended consequences and implications for sustainable phosphorus management. Nutr. Cycling Agroecosyst. 104:373-392. doi: 10.1007/s10705-015-9748-8

Duiker, S.W., and D.B. Beegle. 2006. Soil fertility distribution in long-term no-till, chisel/disk and moldboard plow/disk systems. Soil Tillage Res. 88:30-41. doi:10.1016/j.still.2005.04.004

Eckert, D.J., and J.W. Johnson. 1985. Phosphorus fertilization in no-tillage corn production. Agron. J. 77:789-792. doi:10.2134/agronj1985.00021962007 $700050028 \mathrm{x}$

Farmaha, B.S., F.G. Fernández, and E.D. Nafziger. 2012. Distribution of soybean roots, soil water, phosphorus and potassium concentrations with broadcast and subsurface-band fertilization. Soil Sci. Soc. Am. J. 76:1079-1089. doi: $10.2136 /$ sssaj2011.0202

Fernández, F.G., and D. Schaefer. 2012. Assessment of soil phosphorus and potassium following real time kinematic-guided broadcast and deep-band placement in strip-till and no-till. Soil Sci. Soc. Am. J. 76:1090-1099. doi:10.2136/sssaj2011.0352

Friedrich, T., R. Derpsch, and A. Kassam. 2012. Overview of the global spread of conservation agriculture. Field Actions Science Reports, Special Issue 6. http://factsreports.revues.org/1941 (accessed 6 Feb. 2017).

Lupwayi, N.Z., G.W. Clayton, J.T. O’Donovan, K.N. Harker, T.K. Turkington, and Y.K. Soon. 2006. Soil nutrient stratification and uptake by wheat after seven years of conventional and zero tillage in the Northern Grain belt of Canada. Can. J. Soil Sci. 86:767-778. doi:10.4141/S06-010

Messiga, A.J., N. Ziadi, A. Mollier, L.-E. Parent, A. Schneider, and C. Morel. 2015. Process-based mass-balance modeling of soil phosphorus availability: Testing different scenarios in a long-term maize monoculture. Geoderma 243-244:41-49. doi:10.1016/j.geoderma.2014.12.009

Messiga, A.J., N. Ziadi, C. Morel, C. Grant, G. Tremblay, G. Lamarre, and L.-E. Parent. 2012. Long term impact of tillage practices and biennial $P$ and $N$ fertilization on maize and soybean yields and soil P status. Field Crops Res. 133:10-22. doi:10.1016/j.fcr.2012.03.009

Messiga, A.J., N. Ziadi, C. Morel, and L.-E. Parent. 2010. Soil phosphorus availability in no-till versus conventional tillage following freezing and thawing cycles. Can. J. Soil Sci. 90:419-428. doi:10.4141/CJSS09029

Nolin, M.C., M.J. Caillier, and C. Wang. 1991. Soil variability and sampling method in detailed soil surveys of the Montreal lowlands area [in French, abstract in English]. Can. J. Soil Sci. 71:439-451. doi:10.4141/cjss91-043

Nyiraneza, J., M.C. Nolin, N. Ziadi, and A.N. Cambouris. 2011. Short-range variability of nitrate and phosphate desorbed from anionic exchange membranes. Soil Sci. Soc. Am.J.75:2242-2250. doi:10.2136/sssaj2011.0141

Oliver, M.A., and R. Webster. 2014. A tutorial guide to geostatistics: Computing and modelling variograms and kriging. Catena 113:56-69. doi:10.1016/j. catena.2013.09.006

Pittelkow, C.M., X. Liang, B.A. Linquist, K.J. van Groenigen, J. Lee, M.E. Lundy, N. van Gestel, J. Six, R.T. Venterea, and C. van Kessel. 2015. Productivity limits and potentials of the principles of conservation agriculture. Nature 517:365-368. doi:10.1038/nature 13809

Poirier, V., D.A. Angers, P. Rochette, M.H. Chantigny, N. Ziadi, G. Tremblay, and J. Fortin. 2009. Interactive effects of tillage and mineral fertilization on soil carbon profiles. Soil Sci. Soc. Am. J. 73:255-261. doi:10.2136/ sssaj2008.0006

Puustinen, M., J. Koskiaho, and K. Peltonen. 2005. Influence of cultivation methods on suspended solids and phosphorus concentrations in surface runoff on clayey sloped fields in boreal climate. Agric. Ecosyst. Environ. 105:565-579. doi:10.1016/j.agee.2004.08.005

Robertson, G.P. 2008. GS+: Geostatistics for the environmental sciences. Version 9. Gamma Design Software, Plainwell, MI.

Rodrigues, M., P.S. Pavinato, P.J.A. Withers, A.P.B. Teles, and W.F.B. Herrera. 2016. Legacy phosphorus and no tillage agriculture in tropical oxisols of the Brazilian savanna. Sci. Total Environ. 542:1050-1061. doi:10.1016/j. scitotenv.2015.08.118

SAS Institute. 2010. SAS User’s Guide: Statistics. Version 9.3. SAS Institute Inc., Cary, NC.

Shi, Y., N. Ziadi, A.J. Messiga, R. Lalande, and Z. Hu. 2013. Changes in soil phosphorus fractions for a long-term corn-soybean rotation with tillage and phosphorus fertilization. Soil Sci. Soc. Am. J. 77:1402-1412. doi:10.2136/ sssaj2012.0427

Simard, R.R., S. Beauchemin, and P.M. Haygarth. 2000. Potential for preferential pathways of phosphorus transport. J. Environ. Qual. 29:97-105.

Soil Survey Staff. 2010. Keys to soil taxonomy. 11th ed. USDA-NRCS, Washington, DC.

Statistics Canada. 2016. 2011 farm and farm operator data. http://www.statcan.gc.ca/ pub/95-640-x/2011001/p1/p1-05-eng.htm\#XV (accessed 19 Jan. 2017).

Syers, J.K., A.E. Johnston, and D. Curtin. 2008. Efficiency of soil and fertilizer phosphorus use: Reconciling changing concepts of soil phosphorus behaviour with agronomic information. FAO Fertilizer and Plant Nutrition Bulletin 18. Food and Agriculture Organization of the United Nations, Rome.

Webster, R., and M.A. Oliver. 1992. Sample adequately to estimate variograms of soil properties. Eur. J. Soil Sci. 43:177-192. doi:10.1111/j.1365-2389.1992.tb00128.x

Webster, R., and M.A. Oliver. 2007. Geostatistics for environmental scientists, 2nd ed. John Wiley \& Sons, Chichester, UK. doi:10.1002/9780470517277

Zhang, T.Q., A.F. MacKenzie, B.C. Liang, and C.F. Drury. 2004. Soil test phosphorus and phosphorus fractions with long-term phosphorus addition and depletion. Soil Sci. Soc. Am. J. 68:519-528. doi:10.2136/sssaj2004.5190

Ziadi, N., D.A. Angers, B. Gagnon, R. Lalande, C. Morel, P. Rochette, and M.H. Chantigny. 2014. Long-term tillage and synthetic fertilization affect soil functioning and crop yields in a corn-soybean rotation in eastern Canada. Can. J. Soil Sci. 94:365-376. doi:10.4141/cjss2013-067

Ziadi, N., and T. S. Tran. 2007. Mehlich 3-extractable elements. In: M.R. Carter and E.G. Gregorich, editors, Soil sampling and methods of analysis. 2nd ed. CRC Press, Boca Raton, FL. p. 81-88. 